\title{
APLIKASI PROGRAM LINIER DALAM PEMBELIAN BAHAN BAKU
}

\section{Tri Hernawati}

\author{
Prodi Teknik Industri, Fakultas Teknik, Universitas Islam Sumatera UtaraMedan
}

\begin{abstract}
Abstrak
Pengambilan keputusan pembelian bahan baku merupakan salah satu aspek yang penting guna kelancaran produksi. Kesalahan dalam merencanakan kebutuhan bahan baku berakibat pada perolehan laba yang tidak maksimal. Untuk menghindari kesalahan perlu digunakan metode yang tepat. Program Linier (Linear Programming) merupakan salah satu metode yang cukup bermanfaat untuk optimasi pembelian bahan baku dengan melihat keterbatasan sumberdaya perusahaan.. Pada penelitian yang dilakukan, perusahaan membeli bahan baku dari tiga pemasok yang berbeda dengan kapasitas dan harga per-satuan berbeda pula Perusahaan juga memiliki keterbatasan gudang penyimpanan bahan baku. Tujuan yang ingin dicapai adalah minimisasi total biaya pembelian bahan baku. Tahapan yang dilalui dalam aplikasi metode program linier dalam tulisan ini pertama penentuan variabel yang berpengaruh terhadap tujuan, sumberdaya yang dibutuhkan dan yang tersedia; kedua formulasi model matematika; ketiga penentuan solusi optimal dengan menggunakan software LINDO (Linear Interactive and Discrete Optimizer). Keluaran dari aplikasi adalah jumlah pembelian bahan baku optimal dari masing-masing pemasok. Dari hasil penelitian diperoleh jumlah pembelian bahan baku optimal dari pemasok I, II dan III berturut-turut 1.000 ton ; 550 ton dan 450 ton. Bila penentuan pembelian bahan baku menggunakan metode program linier dibandingkan dengan kebijakaksanan yang dilakukan perusahaan selama ini diperoleh penghematan biaya sebesar $23,98 \%$
\end{abstract}

Kata kata kunci : Aplikasi, Program Linier, Bahan Baku 


\section{Pendahuluan}

Ketersediaanbahanbakusangantpentinguntukke lancaranproduksi. Kekuranganbahanbakupada proses produksidapatmenyebabkankerugian yang besarpadaperusahaan. Proses produksiakanterganggubahkanterhentidanmeng akibatkanperusahaantidakdapatmencapaikuanti tasproduksi yang seharusnyadicapai, kehilanganpenjualandankehilangankepercayaa nkonsumen.

Sebaliknyakelebihanbahanbakumenyebabkante rtanamnyainvestasidalambentukpersediaan.

Dari penelitian yang dilakukandiketahuibahwaperusahaanmelakuka npembelianbahanbakudaritigapemasok yang mempunyaikapasitasdanharga per-unit yang berbeda sehingga sering timbulmasalahdalammenentukankuantitasbaha nbakudarimasing-masingpemasok.

Berdasarkan latar belakang tersebut maka permasalahan yang akan dibahas adalah berapa jumlah bahan baku optimal dari masing-asing pemasok agar total biaya minimal. Optimasi dilakukakan dengan mengaplikasikanmetode program linier.

\section{Tujuan}

Tujuan dilakukannya penelitian adalah untuk menentukan jumlahpembelian bahan baku optimal dari masing-masing pemasok dengan menggunakan program linier dengan mempertimbangkan keterbatasan gudang, kapasitas dari masing-masing pemasok serta biaya pembelian per-satuan dari masingmasing pemasok untuk meminimalkan biaya.

\section{Tinjauan Pustaka}

\section{Program Linier (Linear Programming)}

Permasalahan optimasi dengan keterbatasan sumberdaya dapat diselesaikan dengan pendekatan program linier (linear programming), yaitu memaksimumkan atau meminimumkan fungsi tujuan yang tergantung pada sejumlah variabel input. Fungsi tujuan (constraint function) adalah rumusan fungsi yang menjadi sasaran untuk mencapai pemecahan optimum (maksimisasi atau minimisasi), sedangkan fungsi batasan (constraints function) merupakan rumusan dari persediaan sumberdaya yang membatasi proses optimasi.

Pada pembahasan tulisan ini, penulis menggunakan pengertian program llinier dari beberapa penulis yang maknanya pada dasarnya sama walaupun redaksinya berbeda. Menurut Buffa dan Sharin (1987) program linier merupakan model analisis yang dipakai untuk mengalokasikan sumberdaya yang terbatas pada penggunaan sumberdaya yang bersaing dengan cara sedemikian rupa guna mendapatkan pemecahan yang optimum. Chase dan Aquilano (1990), Quilano dan Jacobs (2001) menyatakan program linier merupakan suatu metode pemecahan optlmalisasi secara matematik melalui pengalokasian sumberdaya yang terbatas diantara tipe penggunaan yang bersaing. Optimalisasi tersebut dapat berupa maksimalisasi kontribusi dan dapat pula merupakan minimalisasi biaya. Program linier memuat suatu rencana kegiatan untuk memperoleh hasil yang optimal yang didesain untuk membantu para manajer operasi dalam merencanakan dan membuat keputusan yang diperlukan untuk mengalokasikan sumberdaya (Heizer dan Render, 2005). Dari beberapa pendapat diatas dapat dirumuskan pengertian program linier sebagai sebuah metode matematik yang dipergunakan untuk pemecahan optimum sebuah fungsi tujuan linier melalui pengalokasian sumberdaya yang terbatas yang dimiliki sebuah organisasi atau perusahaan .

\section{Asumsi dalam Program Linier}

- Linierity, mempunyai implikasi bahwa terdapat hubungan garis lurus atau proporstonal diantara variabel yang relevan.

-Additivity, semua fungsi baik fungsi tujuan maupun fungsi kendala tersusun sedemikian rupa sehingga mnunjukkan sifat penjumlahan dengan menambah atau mengurangi jumlah input yang selaras, maka jumlah output yang akan bertambah atau berkurang dengan nisbah yang selaras dengan itu.

- Divisibility, bahwa keluaran (output) yang dihasilkan oeh setiap kegiatan dapat berupa bilangan pecahan. Demikian juga dengan nilai $\mathrm{Z}$ yang dihasilkan.

- Deterministic ,asumsi ini menjelaskan bahwa program linier hanya dapat digunakan sebagai alat pemecahan masalah jika parameter fungsi analisis diketahui dengan pasti. 
- Proportionality, bahwa naik turunnya nilainilai tujuan dan penggunaan sumber/ fasilitas yang tersedia akan berubah secara sebanding (proporsional) dengan perubahan tingkat kegiatan

Secara umum model matematik dari problema program linier dapat diformulasikan sbb :

1. Fungsi yang akan dimaksimumkan atau diminimumkan disebut fungsi tujuan (objective function).

Formulasi Model matematik :

Minimumkan (maksimumkan):

$Z=\sum_{j=1}^{n} C_{j} X_{j}$

atau :

Minimumkan (maksimumkan):

$Z=C_{1} X_{1}+C_{2} X_{2}+\ldots \ldots C_{n} X_{n}$

2. Fungsi Batasan (kendala ) dikelompokkan menjadi 2 macam, yaitu :

- fungsi batasan fungsional, dengan formulasi :

$\sum_{j=1}^{n} a_{i j} X_{j} \leq a t a u=a t a u \geq b_{i}$

atau:

$a_{11} X_{1}+a_{12} X_{2}+\ldots a_{1 n} X_{n} \leq,=, \geq b_{1}$

$a_{21} X_{1}+a_{22} X_{2}+\ldots a_{2 n} X_{n} \leq,=, \geq b_{2}$

$\boldsymbol{a}_{m 1} \boldsymbol{X}_{1}+\boldsymbol{a}_{m 2} \boldsymbol{X}_{2}+\ldots \boldsymbol{a}_{m n} \boldsymbol{X}_{n} \leq,=, \geq \boldsymbol{b}_{n}$

- FungsiBatasan non negative (non negative constraint), denganfoprmulasi :

$X_{i j} \geq 0(\mathrm{i}=1,2,3 \ldots \mathrm{m} ; \mathrm{j}=1,2,3, . . \mathrm{n})$

Keterangan :

$\mathrm{Z}=$ total biaya atau keuntungan

$\mathrm{Cj}$ = biaya atau keuntungan/unit keluaran

$\mathrm{Xj}=$ Jumlah keluaran ke $\mathrm{j}$

$a_{i j}=$ sumberdaya $\mathrm{i}$ yang digunakan untuk keluaran j

Pemecahan persoalan program linier dapat dilakukan secara manual dengan menggunakan metode simpleks. Pada penelitian ini untuk membantu memecahkan masalah digunakan software LINDO (Linear Interactive Discrete Optimizer), yang pada dasarnya menggunakan metode simpleks.

\section{Metodologi}

Metodologi penelitian dapat dilihat pada gambar 1.

tidak

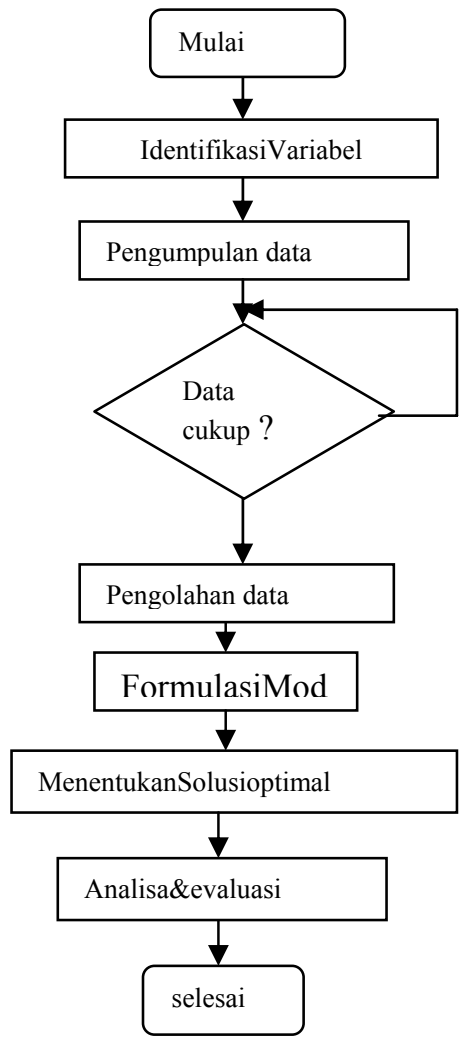

Gambar 1. Tahapanpenelitian

\section{Pengumpulan data}

Data yang dibutuhkan dalam penyelesaian masalah dalam penelitian adalah biaya data pembelian bahan baku dari masing-masing pemasok, data penjualan produk masa lalu, data kapasitas yang dapat disediakan dari masing-masing pemasok serta kapas gudang yang tersedia. Data biaya bahan baku dari masing-masing pemasok dapat dilihat pada Tabel 1.

\section{Tabel 1 . Data Biaya Bahan baku/ton}

\begin{tabular}{clc}
\hline No & \multicolumn{3}{c}{ SumberBiaya } & $($ x Rp 1.000) \\
\hline 1 & Pemasok I & 14.000
\end{tabular}




\begin{tabular}{lll}
2 & Pemasok II & 13.500 \\
3 & PemasokIII & 13.000 \\
\hline
\end{tabular}

Data penjualan produk masa lalu berguna untuk mendapatkan jumlah kebutuhan produk yang dihasilkan pada priode perecanaan. Hal ini diperoleh dengan melakukan peramalan . Setelah diketahui jumah produk yang direncanakan, maka dapat ditentukan jumlah kebutuhan bahan baku . Data kapasitas yang dapat disediakan dari masing-masing pemasok (tabel 2) serta kapasitas gudang yang tersedia yaitu sebesar 2.400 ton.

Tabel 2. Bahan baku yang dapat disediakan

\begin{tabular}{|c|c|c|}
\hline \multicolumn{3}{|c|}{ No SumberJumlah (ton) } \\
\hline 1 & Pemasok I & 1.200 \\
\hline 2 & Pemasok II & 750 \\
\hline 3 & PemasokIII & 450 \\
\hline
\end{tabular}

Pihakperusahaanmenetapkanbahanbakudaripe masok I minimal $50 \quad \%$ dari total kebutuhanbahanbaku.

Kebutuhanbahanbakukwartal I sebanyak 2000 ton, sehinggakebutuhanbahanbakukwartal I yang harusdibelidaripemasok I minimal 1.000 ton

\section{Peramalan Produksi}

Untuk menentukan rencana produksi pada priode optimasi dilakukan peramalan dengan metode kuantitatif yaitu metode yang didasarkan pada perhitungan statistik. Peramalan ini menggunakan data historis (data masa lalu) untuk meramalkan sistem di masa yang akan datang. (Heryanto, 1999 ). Metode kuantitatif yang digunakan adalah Metode Time Series (Deret Berkala).

Rumus umum yang digunakan :

1. Trend Konstan : Dt' $=\frac{\sum \mathrm{dt}}{n}$

2. Trend Linier

$$
\mathrm{Dt}^{\prime}=\mathrm{a}+\mathrm{b} . \mathrm{t}
$$

Untukmendapatkannilai a, b, c dapatdigunakanrumus, sebagaiberikut :

$$
\begin{aligned}
& \mathrm{a}=\frac{\sum \mathrm{dt}}{n}-\frac{b \sum t}{n} \\
& b=\frac{n \sum d t \cdot t-\left(\sum d t\right)\left(\sum t\right)}{n \sum t^{2}-\left(\sum t\right)^{2}}
\end{aligned}
$$

3. Trend Kuadratis
Rumus: $\quad \mathrm{Dt}^{\prime}=\mathrm{a}+\mathrm{bt}+\mathrm{ct}^{2}$

Untukmendapatkannilai $a, \quad b$ dapatdigunakanrumus, sebagaiberikut :

$$
\begin{aligned}
& a=\frac{\sum d t-\mathrm{c}\left(\sum t^{2}\right)}{n} \\
& b=\frac{n \sum d t \cdot t-\left(\sum d t\right)\left(\sum t\right)}{n \sum t^{2}-\left(\sum t\right)^{2}} \\
& c=\frac{\sum d t \sum t^{2}-\mathrm{n}\left(\sum t^{2} \cdot d t\right)}{\left(\sum t^{2}\right)^{2}-\mathrm{n} \sum t^{4}}
\end{aligned}
$$

Dimana :

Dt' : Ramalan Permintaan

a dan b : Konstanta

t :Periode Waktu

dt : data aktual ke t

untuk menentukan model peramalan yang sesuai dilakukan perhitungan kesalahan peramalan. Model yang memiliki kesalahan terkecil digunakan untuk meramalkan kebutuhan produk pada masayang akan datang. Besar kesalahan dalam peramalan dapat dihitung dengan menggunakan metode, (Kusuma, 2004):

Mean Square Error (MSE)

$$
\mathrm{MSE}=\frac{\sum_{t=1}^{n}\left(d t-D \mathrm{t}^{\prime}\right)^{2}}{n}
$$

$\mathrm{dt}=$ permintaan pada prtode $\mathrm{t}$

Dt' $=$ hasil peramalan pada priode

\section{Tabel 2. Data Kebutuhan Bahan Baku (ton)}

\begin{tabular}{lcc}
\hline No & Priode & Kebutuhan (ton) \\
\hline 1 & Kwartal I & 2000,00 \\
2 & Kwartal II & 2563,13 \\
3 & Kwartal III & 2861,80 \\
4 & Kwartal IV & 2202,90 \\
\hline
\end{tabular}

\section{Formulasi Model}

Setelah dilakukan pengolahan data tentang parameter-parameter yang dibutuhkan dan ditentukan semua variabel keputusan, langkah selanjutnya adalah membuat formulasi model program linier.

Sebagai tujuan adalah meminimalkan total biaya pengadaan bahan baku dan sebagai kendala adalah keterdiaan gudang bahan baku, kapasitas masing-masing pemasok. Disamping itu permintaan bahan baku juga PekanIlmiahPeriodeke-XXI FT.UISU JI. SM. Raja Teladan Medan 
dibatasi sesuai dengan hasil peramalan produksi yang dilakukan. Dengan diketahuinya jumlah permintaan produk dapat ditentukan kebutuhan bahan baku untuk priode perencanaan

Formulasi model matemtik secara simbolis sbb:

Fungsi Tujuan :

Miniimumkan

$Z=C_{1} X_{1}+C_{2} X_{2}+C_{3} X_{3}$

Batasan : $\sum_{i=1}^{n} a_{i j} X_{j} \leq b_{i}$

$X_{j} \geq 0$

Keterangan :

$\mathrm{Cj}=$ Biaya /unit bahan baku

$\mathrm{Xj}=$ Jumlah bahan yang dibeli dari pemasok ke j

bi = bahan baku yang tersedia pada pemasok i

\section{Solusi Optimal}

Setelah model program linier selesai diformulasikan maka dilakukakan optimasi dengan menggunakan software LINDO ((Linear Interactive and Discrete Optimizer).

\section{Hasil dan Pembahasan}

Setelah dilakukan peramalan, maka ditentukan kesalahan peramalan untuk masing-masing metode. Metode yang mepunyai kesalahan terkecil digunakan untuk menentukan rencana produksi pada priode optimasi. Optimasi dilakukan untuk satu tahun kedepan, tapi dalam tulisan ini yang ditampilkan hanya untuk satu kwartal . Priode lainnya dapat ditentukan dengan cara yang sama. Setelah diperoleh semua parameter yang dibutuhkan, maka dilakukan formulasi model matematik.

Variabel Keputusan :

$\mathrm{X}_{1}=$ jumlah bahan baku yang dibeli dsri pemsok 1

$\mathrm{X}_{2}=$ jumlah bahan baku yang dibeli dari pemasok 2

$\mathrm{X}_{3}=$ jumlah bahan baku yang dibeli dsri pemsok 3

Formulasi model matematik:

Tujuan yang ingin dicapai adalah meminimumkan total biaya pembelian bahanbaku.

PekanIlmiahPeriodeke-XXI FT.UISU Jl. SM. Raja Teladan Medan
Formulasi lengkap model matematik dari persoalan

Fungsi Tujuan :

Minimumkan

$Z=14.000 X_{1}+13.500 X_{2}+13.000 X_{3}$

Penentuan Fungsi Pembatas:

Kapasitas Pemasok I :

$X_{1}$ $\leq 1.200$

Kapasitas Pemasok II :

$X_{2}$ $\leq 750$

Kapasitas pemasok III

$X_{3} \leq 450$

Bahan baku yang harus dibeli dari pemasok I :

$X_{1}$ $\geq 1.000$

Kebutuhan bahan baku:

$X_{1}+X_{2}+X_{3}=2.000$

Kapasitas Gudang :

$X_{1}+X_{2}+X_{3} \leq 2.400$

Pembatas non negatif:

$$
\mathrm{X}_{1}, \mathrm{X}_{2}, \mathrm{X} 3 \geq 0
$$

Setelah dilakukan optimasi dengan solver LINDO, diperoleh hasil sbb :

LP OPTIMUM FOUND AT STEP 1

OBJECTIVE FUNCTION VALUE

1) $0.2727500 \mathrm{E}+08$

$\begin{array}{ccc}\text { VARIABLE } & \text { VALUE } & \text { REDUCED COST } \\ \mathrm{X}_{1} 1000.000000 & 0.000000 \\ \mathrm{X}_{2} 550.000000 & 0.000000 \\ \mathrm{X}_{3} 450.000000 & 0.000000\end{array}$

\section{ROW SLACK OR DUAL PRICE}

SURPLUS

2) $\quad 200.000000 \quad 0.000000$

3) $200.000000 \quad 0.000000$

4) $\quad 0.000000 \quad 500.000000$
5) $\quad 0.000000 \quad-500.000000$
6) $\quad 0.000000 \quad-13500.000000$

7) $\quad 400.000000 \quad 0.000000$ 


\section{8) $\quad 1000.000000 \quad 0.000000$ \\ 9) $\quad 550.000000 \quad 0.000000$ \\ 10) $\quad 450.000000 \quad 0.000000$ \\ NO. ITERATIONS $=1$}

\section{Kesimpulan}

Dari hasil penelitian yang dilakukan dapat disimpulkan bahwa, kebutuhan bahan baku sebanyak 2000 ton pada kwartal I dapat dipenuhi dengan membeli dari masing-masing pemasok, yaitusebanyak 1.000 ton dari pemasok I; 550 ton dari pemasok II dan sebanyak 450 dari pemasok III dengan total biaya $\mathrm{Rp}$ 2.272.750. 000. Selama ini kebijakan perusahaan dalam memenuhi kebutuhan bahan baku melakukan pembelian dari pemasok I sebesar 50\%, pemasok II sebesar $60 \%$ dan pemasok III sebesar 40\%. Bila kebutuhan bahan baku sebanyak 2000 ton, maka biaya pembelian bahan baku sebesar Rp 2.990.000.000. Dengan demikian bila penentuan pembelian bahan baku menggunakan metode program linier dibandingkan dengan kebijakaksanan yang dilakukan perusahaan selama ini diperoleh penghematan biaya sebesar $23,98 \%$

\section{Daftar Pustaka}

Hiller,Frederick S, Gerald J.Lieberman., 1995,Pengantar Rieset Operasi. Edisi kelimaErlangga. Jakarta.

Heizer, Jay \& Render, Barry, 2005,Operation Management. Jakarta. SalembaEmpat.

Linus Schrange, 1991, Lindo An Optimization Modeling SystemSouth Sanfransisco; The Scientific Press

Sudjana, 2001,Metode Statistika. Edisikeenam, Tarsito. Bandung
Siagian P., 1987, Penelitian Operasionalal, Teoridan Praktek. UI. Press, Jakarta

Sutalaksana, Anggawisastra, Tjakra Atmaja., 1980,Teknik Tata Cara Kerja, Edisi PertamaITB, Bandung.

Siswanto, 2007. Operation Research. Jilid I. Erlangga, Jakarta

Taha, H.A., 2005, Riset Operasi Suatu pengantar.Edisi Kelima Binarupa Aksara. Jakarta.

T.HaniHandoko, 1991,DasardasarOperationResearch. Edisi kedua. Jogjakarta.BPPE 
